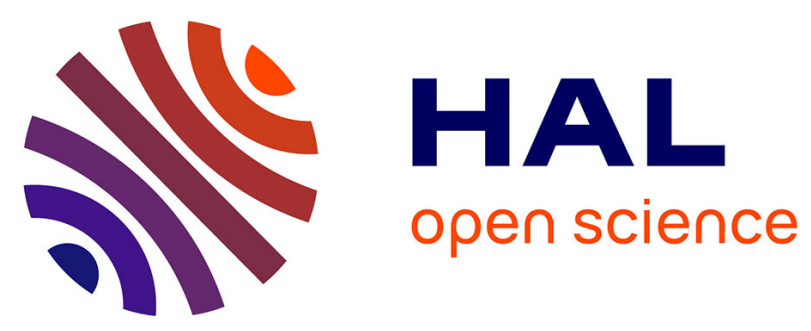

\title{
Organic matter sources and decay assessment in a Sphagnum-dominated peatland (Le Forbonnet, Jura Mountains, France). Impact of moisture conditions.
}

Frédéric Delarue, Fatima Laggoun-Défarge, Jean-Robert Disnar, Nathalie Lottier, Sébastien Gogo

\section{To cite this version:}

Frédéric Delarue, Fatima Laggoun-Défarge, Jean-Robert Disnar, Nathalie Lottier, Sébastien Gogo. Organic matter sources and decay assessment in a Sphagnum-dominated peatland (Le Forbonnet, Jura Mountains, France). Impact of moisture conditions.. Biogeochemistry, 2011, 106 (1), pp.39-52. 10.1007/s10533-010-9410-0 . insu-00457818

\section{HAL Id: insu-00457818 https://hal-insu.archives-ouvertes.fr/insu-00457818}

Submitted on 8 Sep 2010

HAL is a multi-disciplinary open access archive for the deposit and dissemination of scientific research documents, whether they are published or not. The documents may come from teaching and research institutions in France or abroad, or from public or private research centers.
L'archive ouverte pluridisciplinaire HAL, est destinée au dépôt et à la diffusion de documents scientifiques de niveau recherche, publiés ou non, émanant des établissements d'enseignement et de recherche français ou étrangers, des laboratoires publics ou privés. 
Early diagenetic transformations of peat

Original research

Organic matter sources and decay assessment in a Sphagnum-dominated peatland (Le Forbonnet, Jura Mountains, France). Impact of moisture conditions.

Delarue F, Laggoun-Défarge F, Disnar JR, Lottier N, Gogo S

Université d’Orléans, Université François Rabelais - Tours, CNRS/INSU. Institut des Sciences de la Terre d’Orléans

Université d’Orléans, Université François Rabelais - Tours, CNRS/INSU. Institut des Sciences de la Terre d’Orléans UMR 6113. Campus Géosciences. 1A, rue de la Férollerie, 45071 Orléans cedex 2, France.

Telephone number: +33238494660

Fax: +33238636488

E-mail addresses: frederic.delarue@univ-orleans.fr 
KEY WORDS: bioindicators - carbohydrates - labile organic matter - peat botanical composition - PEATWARM - Rock-Eval pyrolysis

\begin{abstract}
In a context of climate change peatlands may switch from a sink to a source of carbon (C). The induced positive feedbacks are closely linked to $\mathrm{C}$ dynamics, and thus to the fate of organic matter (OM) in the underlying peat. Our aims were to determine how moisture conditions in a Sphagnum-dominated peatland affect the dynamics of diagenetic sensitive OM which is thought to be the most reactive to warming effects. The approach was based on the identification of combined bulk and molecular bioindicators of OM sources and decay of peat profiles (up to $50 \mathrm{~cm}$ in depth) from two moisture conditions of the Le Forbonnet peatland (Jura Mountains, France). The (xylose+arabinose)/(galactose+rhamnose+mannose) ratio derived from the analysis of neutral monosaccharides was used to obtain indications on the botanical origin of the peat and tended to indicate a greater contribution of Cyperaceae in the deepest parts of the peat. Most bioindicators showed that OM decay increased with depth and was higher in the driest conditions. In these conditions, decay was shown by a loss of diagenetic sensitive oxygen-rich OM, probably leached by water table fluctuations. Decay intensity was also shown by the high ribose and lyxose contents at the peat surface, where microscopic observations also revealed relatively large quantities of fungal hyphae. The sugars could have arisen from microbial synthesis, primarily protozoan and fungal activity. These results suggest that water level changes preferentially impact biochemical changes in diagenetic sensitive OM, believed to be sensitive to drought events.
\end{abstract}

\title{
ABBREVATIONS
}

AOM: Amorphous organic matter

Ar: Arabinose

C: Carbon

Ga: Galactose

HC: Hydrocarbons

HI: Hydrogen index

Ma: Mannose

OI: Oxygen index

OM: Organic matter 
PPI: Pyrophosphate index

Rh: Rhamnose

TOC: Total organic content

Xy: Xylose 


\section{INTRODUCTION}

Peatlands act as carbon (C) sinks as a result of cool and anoxic conditions favourable to reduced rates of decay (Clymo 1983; Moore \& Knowles 1990). Northern hemisphere peatlands contain 1/3 of the world's soil C stock (Gorham 1991) in an area accounting for only 3-5\% of total terrestrial surface (Maltby \& Immirzi 1993). Sphagnum-dominated peatlands are primarily situated in northern and subarctic zones where climate changes are expected to be strongly marked (Gore 1983; Bridgham et al. 2001; Houghton et al. 2001). These changes would impact $C$ sequestration and change peatlands into a net source of $C$ (Waddington \& Roulet 1996; Bubier et al. 1999; Dorrepaal et al. 2009) providing positive feedback (Kirschbaüm 1995). C sequestration in peatlands is closely linked with spatial variability in their habitats due to different wetness conditions (Belyea \& Malmer 2004). The high C pool in peatlands is mainly due to high water levels and consequent anoxia. As such, the sequestered organic matter (OM) in peatlands is labile, i.e. made of biochemically unstable organic compounds, and sensitive to changes in environnemental conditions. Many studies have shown the impact of wetness conditions on gas exchanges (e.g., Waddington \& Roulet 1996; Christensen et al. 2000; Heikkinen et al. 2002; Strack et al. 2006, Bortoluzzi et al. 2006), primary production (e.g., Pedersen 1975; Gerdol 1995; Gunnarsson 2005) or C losses due to microbial respiration and leaching of water-soluble compounds (e.g., Johnson \& Damman 1991; Hogg et al. 1994; Belyea 1996). However, only a few studies have dealt with the in situ dynamics of peat decomposition and have described the fate of labile OM in early decay phases, particularly in ombrotrophic peatlands. In these ecosystems, the fate of OM has been studied primarily by using molecular indicators, e.g. carbohydrates, as they have been identified as a major OM pool in the studied peats (Comont et al. 2006; Jia et al. 2008; Laggoun-Défarge et al. 2008). The amounts and the distributions of carbohydrates in peats, soils and sediments have been used to identify specific signatures of phyto-inheritance and in situ microbial synthesis (Hamilton \& Hedges 1988; Moers et al. 1990). Thus, Comont et al. (2006) combined bulk and molecular indicators in a cut-over peatland to determine plant source indicators such as xylose and arabinose for Cyperaceae inputs, and galactose, rhamnose and mannose for moss inputs. Other sugars such as lyxose and allose were also quantified but their origins remained unclear. These authors also attributed ribose and fucose to a likely microbial synthesis whereas Jia et al. (2008) indicated that fucose could be a potential indicator of Sphagnum-derived OM. Bulk organic geochemical analyses also proved to be efficient in revealing both the botanical origin of the $\mathrm{OM}$ and the degradation processes 
that these precursors underwent, particularly in peat horizons. For example, light microscopy observations and counting have been successfully used on whole peats to describe the sources of plant-derived tissues as well as the status of decomposition in different horizons (LaggounDefarge et al. 1999; Bourdon et al. 2000; Comont et al. 2006). Another bulk measure often used as a classification tool in peatlands is pyrophosphate index (PPI) (Kaila 1956; Clymo 1983). PPI is a method allowing humified OM to be semi-quantitatively estimated (Gobat et al. 1986). Schnitzer (1967) showed that it partially reflected the amounts of humified compounds as it was correlated only with fulvic acids. Rock-Eval pyrolysis is a commonly used technique developed to diagnose oil-producing hydrocarbon source rocks by measuring the amounts of hydrocarbonaceous and oxygenated compounds cracked during the pyrolysis cycle and by determining the temperature of maximum hydrocarbon cracking (Espitalié et al., 1985a, b; Lafargue et al., 1998). The technique was further adapted to assess the biochemical quality of soil OM (Di-Giovanni et al. 1998; Disnar et al. 2003; Sebag et al. 2006). Disnar et al (2003) showed that Rock-Eval parameters can reveal the chemical evolution of the OM during the process of humification. In the present study, two parameters (R400 and R330) were determined through decomposition of the pyrolysis S2 peak recorded during programmed pyrolysis in an inert atmosphere $\left(\mathrm{N}_{2}\right)$. These parameters were particularly used to assess qualitative changes that affect OM, chiefly its thermolability, from two hydrological sites and with increasing humification in the peat profiles of the peatland.

The aim of the present study was to assess how moisture conditions affect the dynamics of peat OM, especially the labile component as it is the most sensitive to changes in environmental conditions. We first determined the impact of botanical variability on biochemical OM signatures to be able to subsequently interpret their variations in terms of differential decay of OM. In addition to carbohydrate amounts and distribution, we used bulk organic geochemical analyses (PyroPhosphate Index, optical microscopy and Rock Eval pyrolysis) to determine the biochemical and morphological characteristics of peat profiles (50 cm long) at sites at different hydrological conditions (WET and DRY) from Le Forbonnet peatland in the French Jura Mountains.

\section{MATERIAL AND METHODS}

\section{Study site and sampling}


The Forbonnet peatland (4649’35” N; 6¹0’20” E, altitude $836 \mathrm{~m}$ a.s.l.) is an undisturbed ombrotrophic Sphagnum-dominated mire situated in eastern France, in the French Jura mountains, near Frasne (Doubs Department; Figure 1). The mean annual precipitation and temperature are 1300 to $1500 \mathrm{~mm}$ and $7-8^{\circ} \mathrm{C}$ respectively. The peatland is protected by the EU Habitat Directive of Natura 2000 and has been classified as a Regional Natural Reserve for more than 20 years.

The moss cover dominated by Sphagnum fallax, S. magellanicum and S. warnstorfii is about 85-95\% while the cover of herbaceous plants is about 60\%. Vascular plants are primarily represented by Eriophorum vaginatum, Scheuchzeria palustris, Andromeda polifolia, Vaccinium oxycoccos and Carex limosa. Among shrubs, Calluna vulgaris is also found (Bailly 2005). Two sites in the peatland were selected in relation to their hydrology and functional groups of plants: (i) a transitional poor fen site named "WET” characterised by the lack of S. magellanicum and small quantities of E. vaginatum, (ii) an open bog site named "DRY" with mixed vegetation (Sphagnum fallax, S. magellanicum, E. vaginatum and Vaccinium oxycoccus) (Buttler, unpublished data). Existing data do not allow us to assess the annual mean water table level at these two sites. The distinction between these sites was therefore based on vegetation composition as it is largely determined by water level (Wheeler and Proctor, 2000; Økland et al., 2001). S. fallax which is considered as a hollow and lawn species dominates the WET site, whereas $S$. magellanicum which is particularly characteristic of hummocks is present only in the DRY site (Pedersen 1975; Gerdol 1995; Francez 2000). In addition, the so-called DRY site is characterised by the abundance of E. vaginatum species and associated hummocks where the water level is lower than in hollows (Johnson \& Damman 1991).

Three replicates of $13 \mathrm{~cm}$ diameter peat cores were extracted in June 2008 from each of the two sites for a total of 6 cores (D1, D2, D4 in the DRY site and W7, W11, W12 in the WET site). The fifty $\mathrm{cm}$ long cores were cut into $2.5 \mathrm{~cm}$ slices that were subsampled for various analyses. One subsample was dried and grinded and then stored at $4^{\circ}$ until used for chemical analyses. Another subsample was kept wet for micromorphological analysis. Cores D1 and W12, located at the extremity of the DRY and WET sites respectively, were exhaustively analysed. In contrast in cores D2, D4, W7 and W11 the analyses were focused on the three successive upper levels (2.5 to $10 \mathrm{~cm}$ depth) and only selected samples at depth. Sugar analyses were performed only on two cores, D1 and W12 with a similar sampling as for D2, D4, W7 and W11. 


\section{Methods}

\section{TOC analysis}

Carbon analysis was determined by combustion of dried and crushed samples at $1100^{\circ} \mathrm{C}$, using a CNS-2000 LECO apparatus. Because of the absence of carbonates, total carbon was assumed to be Total Organic Carbon (TOC).

\section{Micro-morphological analysis}

Light microscopy observations enabled organic components (plant organ-derived tissues, amorphous material, microbial secretions and micro-organisms) to be identified and quantified. Wet bulk peat samples were mounted as smear slides and examined at 20 and 50X magnifications. The surfaces covered by the primary organic micro-remains were estimated with a reticulated eyepiece. A total of 3000 to 5000 items per sample were counted to calculate relative frequencies with an estimated error of about 10\% (Noël 2001).

\section{Rock-Eval pyrolysis}

These analyses were carried out on ca. $30 \mathrm{mg}$ of powdered dry peat with a Rock-Eval ${ }^{\circledR}$ "Turbo" 6 pyrolyser (Vinci Technologies). The full description of the method can be found in Espitalié et al. (1985a, b) and Lafargue et al. (1998). Briefly, the samples first undergo programmed pyrolysis (under $\mathrm{N}_{2}$ ) from 200 to $650^{\circ} \mathrm{C}$ at a rate of $30^{\circ} \mathrm{C} \mathrm{min}{ }^{-1}$, then the residue of pyrolysis is oxidized under air in a second oven. The amounts of hydrocarbons released at the start and during the pyrolysis phase [S1 and S2, respectively; in mg hydrocarbons (HC) $\mathrm{g}^{-}$ ${ }^{1}$ ] are quantified thanks to a flame ionisation detector; the $\mathrm{CO}$ and the $\mathrm{CO}_{2}$ released during the pyrolysis and oxidation phases (S3CO/S3CO 2 and $\mathrm{S} 4 \mathrm{CO} / \mathrm{S}_{4} \mathrm{CO}_{2}$, respectively) are quantified by online infrared detectors. The Rock-Eval parameters used for this study are the following: (i) Total Organic Carbon (TOC, wt \%) accounts for the quantity of organic carbon present in the sample and is calculated by weighed addition of the amounts of all the effluents of pyrolysis and oxidation (S1, S2, S3CO...; see above); (ii) the Hydrogen Index (HI, in mg $\mathrm{HC}^{-1}$ TOC) is the amount of hydrocarbon products released during pyrolysis (S2), normalized to TOC; (iii) the Oxygen Index (OI RE6, in $\mathrm{mg} \mathrm{O}_{2} \cdot \mathrm{g}^{-1} \mathrm{TOC}$ ) is similarly calculated from the amounts of $\mathrm{CO}_{2}$ and $\mathrm{CO}$ released during pyrolysis $\left(\mathrm{S} \mathrm{CO}_{2}\right.$ and $\left.\mathrm{S} 3 \mathrm{CO}\right)$, normalized to TOC. In addition, we also used the R400 parameter which represents the part of the S2 signal produced below $400^{\circ} \mathrm{C}$ (Disnar et al., 2003; Figure 2) and we similarly introduced the R330 parameter which corresponds to the part of the S2 signal produced below $330^{\circ} \mathrm{C}$ (Figure 2). According to previous work (Disnar et al., 2003; Sebag et al., 2006) R330 
and R400 should roughly express the proportions of the most thermolabile compounds and of the biopolymers (namely cellulose and lignin; Disnar et al. 2008),

\section{Figure 2}

\section{Pyrophosphate index}

The pyrophosphate index was determined by the Kaila method (1956) and calculated following Gobat et al. (1986). Humic compounds were extracted from peat (0.5g) with 0.025 M sodium pyrophosphate overnight. The mixtures were filtered (Whatman, 2V) and the filtrates were diluted to $250 \mathrm{ml}$ with deionised water. The absorbance of the solution was measured at $550 \mathrm{~nm}$ with a Hitachi U1100 spectrophotometer. The pyrophosphate index was obtained by multiplying the measured absorbance by 100 .

\section{Carbohydrate analysis}

The detailed method has been described elsewhere (Comont et al., 2006). The analysis is carried out in two independent steps to release hemicellulosic and total (i.e. hemicellulosic and cellulosic) sugars, respectively. Both steps comprise polysaccharide hydrolysis with dilute acid solution, but only after previous soaking with concentrated acid for total sugar analysis. Thus, the operating procedure for total sugar analysis can be summarized as follows: $1 \mathrm{ml}$ of $24 \mathrm{~N} \mathrm{H}_{2} \mathrm{SO}_{4}$ was added to 20 to $30 \mathrm{mg}$ of dry peat in a Pyrex ${ }^{\circledR}$ tube. After $16 \mathrm{~h}$ at room temperature, the samples were diluted to $1.2 \mathrm{M} \mathrm{H}_{2} \mathrm{SO}_{4}$. The tubes were closed tightly under vacuum and heated at $100^{\circ} \mathrm{C}$ for $4 \mathrm{~h}$. After cooling, deoxy-6-glucose (0.4 mg.ml-1 in water) was added as internal standard (Wicks et al., 1991). The samples were subsequently neutralised with $\mathrm{CaCO}_{3}$. The precipitate was removed by centrifugation and the supernatant was evaporated to dryness. The sugars were then dissolved in $\mathrm{CH}_{3} \mathrm{OH}$ and the solution was purified by centrifugation. After transferring the solution to another vessel, the solvent was evaporated under vacuum. The sugars were dissolved in pyridine containing $1 \mathrm{wt} \% \mathrm{LiClO}_{4}$ and left $16 \mathrm{~h}$ at $60^{\circ} \mathrm{C}$ for anomer equilibration (after Bethge et al. 1996), then they were silylated (Sylon BFT, Supelco) and analysed using a Perkin-Elmer gas chromatograph fitted with a $25 \mathrm{~m} \times 0.25 \mathrm{~mm}$ i.d. CPSil5CB column $(0.25 \mu \mathrm{m}$ film thickness $)$ and a flame ionization detector. The oven temperature was raised from 60 to $120^{\circ} \mathrm{C}$ at $30^{\circ} \mathrm{C} \mathrm{min}-1$, maintained there for $1 \mathrm{~min}$, and raised to $240^{\circ} \mathrm{C}$ at $3^{\circ} \mathrm{C} \cdot \mathrm{min}^{-1}$ and finally at $20^{\circ} \mathrm{C} \cdot \mathrm{min}^{-1}$ to $310^{\circ} \mathrm{C}$, at which it was maintained for $10 \mathrm{~min}$. The injector split was off at the start and turned on after $2 \mathrm{~min}$. The injector was maintained at $240^{\circ} \mathrm{C}$ and the detector at $300^{\circ} \mathrm{C}$. A mixture of 
ten monosaccharides (ribose, arabinose, xylose, rhamnose, fucose, glucose, mannose and galactose, lyxose and allose) was used as external standard for compound identification through peak retention times and for individual response coefficient determination. Replicate analyses gave an analytical precision between 10 to $15 \%$.

\section{RESULTS}

\section{Carbon contents}

Total organic carbon contents are high (42.4 to 48.3\%; Figure 3a) showing no significant dilution by inorganic inputs (Bourdon et al. 2000; Laggoun-Défarge et al. 2008). TOC contents systematically increased with increasing depth (42.5 to 48.2\%). Overall, the TOC in the DRY situation was higher than WET TOC. It is to be noted that this difference was observed in the first $25 \mathrm{~cm}$, where DRY TOC contents were in the range of 45.1 to $45.7 \%$, compared to WET values of 42.5 to $43.5 \%$ (Figure 3a). Below $25 \mathrm{~cm}$ depth, the difference between DRY and WET is less marked (46.7 to $48.2 \%$ vs. 44.3 to $47.0 \%$ respectively).

\section{Figure 3}

\section{Micro-morphological characteristics}

The observed organic micro-remains were present as (i) well-preserved tissues (11 to 89\%; Figure 4a) and structureless tissues (7 to 56\%) derived from vascular plants and mosses, (ii) mucilage (up to 30\%; Figure 4b) partly derived from in situ microbial syntheses by bacteria, fungi and/or plant roots (Laggoun-Défarge et al. 1999). Three other minor components were also present as (i) amorphous OM (0 to 7\%; Figure 4c), (ii) tangled masses of melanised fungal hyphae (0.2 to 3.6\%; Figure 4d) often associated with decayed plants and amorphous $\mathrm{OM}$ and (iii) micro-organisms (0 to 1.4\%) represented by algae, testate amoebae and diatoms. In both WET and DRY sites, the relative abundance of well-preserved tissues decreased with increasing depth (from 89 to 32\% in WET and 66 to 11\% in DRY, Figure 4a) while mucilage contents increased (from 1 to 19\% in WET and 7 to 30\% in DRY; Figure 4b). These features document typical diagenetic OM changes with increasing depth. These two major families of components exhibited contrasting proportions between WET and DRY sites, the wellpreserved tissues being more abundant in the WET site while mucilage was lower and even absent at the peat surface.

The percentages of amorphous organic matter (AOM) remained relatively constant with depth (0 to 7\%; Figure 4c). There was no marked difference between WET and DRY sites, except 
that AOM was absent in the most superficial levels in the WET condition. The relative abundance of mycelial hyphae varied irregularly with depth (Figure 4d) but in globally lower proportions in the WET than in the DRY conditions, especially in the first $15 \mathrm{~cm}(0.2$ to $0.8 \%$ vs. 1.2 to $3.6 \%)$.

\section{Figure 4}

\section{Rock-Eval Pyrolysis parameters}

HI values were relatively high throughout the series, i.e. between 370 and $454 \mathrm{mg} \mathrm{HC}_{\mathrm{g}} \mathrm{g}^{-1}$ TOC (Figure 3c), as expected for a material believed to have arisen primarily from terrestrial plants (Espitalié et al. 1985a, b). Even so, the behaviour of this parameter differed between WET and DRY conditions. In the WET site, there was little HI change with depth (400 to 410 mg HC.g ${ }^{-1}$ TOC) while in DRY it decreased from 427 to 386 HC.g $^{-1}$ TOC at $25 \mathrm{~cm}$, and then remained stable in the deepest levels. The behaviour of the OI also differed with depth. In the WET conditions, it decreased considerably from 263 to $186 \mathrm{mg} \mathrm{O}_{2} \cdot \mathrm{g}^{-1}$ TOC (Figure 3d), whereas the decrease in DRY conditions was lower (193 to $169 \mathrm{mg} \mathrm{O}_{2} \cdot \mathrm{g}^{-1} \mathrm{TOC}$ ) and occurred from a depth of $25 \mathrm{~cm}$ (Figure 3d). R400 and R330 ratios showed distinctive trends with depth in the DRY and WET sites, particularly in the ca. $30 \mathrm{~cm}$ uppermost peat. As for the OI parameter, depth-related changes in these ratios are more pronounced in the WET site, where R400 decreased from 0.71 to 0.62 (Figure 3e), and R330 from 0.37 to 0.28 (Figure 3f). However, in the DRY site, R400 was constant in the uppermost ca. $30 \mathrm{~cm}$ peat (ca. 0.64) and R330 increased only slightly (0.27 to 0.30$)$. Below that depth, both R400 and R330 ratios decreased (0.64 to 0.59 and 0.32 to 0.25 respectively) and approached the same values as in the WET site.

\section{Pyrophosphate index}

The pyrophosphate index (PPI) was more or less constant in the first $30 \mathrm{~cm}$ at both WET and DRY sites (Figure 3b) but increased below that depth from 6.0 to 8.0 in the WET site and from 8.4 to 12.0 in the DRY one. The PPI in WET was lower than in DRY, the difference being evident especially in the first $30 \mathrm{~cm}$ (5.8 to 5.9 in WET vs. 8.3 to 9.3 in DRY).

\section{Carbohydrate contents and distributions}

Quantitative data on sugars and their monomers (Table 1, Figure 5) show that total sugar contents varied between the two conditions studied. In the WET conditions, total sugar 
contents decreased with depth (381.8 to $284.7 \mathrm{mg} \cdot \mathrm{g}^{-1}$ ), while in DRY, they varied from 232.8 to $395.4 \mathrm{mg}^{-1} \mathrm{~g}^{1}$ with no clear-cut trend along the profiles. Sugars comprise cellulose and hemicellulose monomers. Regardless of wetness conditions, cellulose sugars, largely dominated by glucose, changed concomitantly with total sugar contents (Figure 5), namely from 26.7 to $177.4 \mathrm{mg} \cdot \mathrm{g}^{-1}$ and from 66.1 to $161.5 \mathrm{mg} \cdot \mathrm{g}^{-1}$ in the WET and DRY sites, respectively (Table 1). Hemicellulose sugars varied little in the first ca. $30 \mathrm{~cm}$ of the analysed cores, their total concentration amounting to about $200 \mathrm{mg} \cdot \mathrm{g}^{-1}$ in the first $30 \mathrm{~cm}$, regardless of wetness conditions (Table 1). Below $30 \mathrm{~cm}$ depth, hemicellulose sugar contents tended to slightly decrease, especially in the DRY site (210.6 to $142.0 \mathrm{mg}^{-1} \mathrm{~g}^{-1}$ Figure 5, Table 1). Changes in the levels of galactose, rhamnose and mannose paralleled those of total hemicellulose sugars (Figure 5). The WET and DRY sites could be differentiated by their arabinose contents and not by those of galactose, rhamnose and mannose. This distinction involved lower contents of arabinose at the WET than at the DRY site, particularly in the uppermost $25 \mathrm{~cm}$ peat layer (Table 1; Figure 5). Below $25 \mathrm{~cm}$ depth, the two sites could no longer be distinguished by these sugar contents (Figure 5). Xylose contents exhibited no particular different trends with depth and so could not be used to differentiate the WET from the DRY sites (Figure 5).

\section{Figure 5}

The ratio of (xylose + arabinose)/(galactose + rhamnose + mannose) increased with depth and was slightly lower in the WET than in the DRY site in superficial peat (Figure 5). The contents of hemicellulose glucose (Table 1), a ubiquitous monomer, decreased with depth, with no noticeable difference between the WET and DRY sites (Figure 5).

The contents of fucose, allose, ribose, and lyxose were low (Table 1) especially when compared to the above-mentioned monomers. Fucose amounts varied little with depth except in the deepest layer where values reached their maximum (Figure 5). However, the contents of this compound were lower in the WET site than in the DRY one (Table 1). There were no depth-related changes of allose, lyxose and ribose. Ribose and lyxose enabled WET and DRY sites to be distinguished in the first $25-30 \mathrm{~cm}$, since the amounts of these compounds were low in WET conditions whereas higher values were found at certain depths in the DRY situation (Table 1; Figure 5). Allose contents changed little with depth in both conditions (Figure 5), except at 2.5-5 cm and 30-32.5 cm in WET conditions where concentrations were 2 to 3 times higher than in the DRY site. 


\section{DISCUSSION}

\section{Biochemical signatures of OM precursors}

One of the major difficulties with certain biochemical OM markers is that they are indicators of both plant sources and OM decay. To overcome this difficulty, it is advisable first to determine the impact of botanical variability on biochemical OM signatures to be able to subsequently interpret their variations in terms of differential decay of OM.

The amounts of carbohydrates, and especially of hemicellulose sugars, are relatively high and almost constant in the first 25 or $30 \mathrm{~cm}$ in both DRY and WET situations, denoting high preservation of these biopolymers (Table 1). In a first approximation these compounds can therefore be considered as good botanical source indicators, provided that the original plants have distinctive hemicellulosic sugar compositions. Previous work has shown that Cyperaceae are rich in xylose (Wicks et al. 1991; Bourdon et al. 2000) as well as in arabinose (Moers et al. 1989, 1990; Comont et al. 2006). Conversely, galactose, mannose and rhamnose are adequate indicators of mosses, in particular Sphagnum spp. and Polytrichum spp. (Popper \& Fry 2003; Comont et al. 2006). Accordingly, Comont et al. (2006) used the $(\mathrm{Xy}+\mathrm{Ar}) /(\mathrm{Ga}+\mathrm{Rh}+\mathrm{Ma})$ ratio to reconstitute the respective parts played by these two major botanical sources in peat formation. The slight increase with depth in the $(\mathrm{Xy}+\mathrm{Ar}) /(\mathrm{Ga}+\mathrm{Rh}+\mathrm{Ma})$ ratio in the profiles examined (Figure 5), indicates a greater contribution from vascular plants (i.e. Eriophorum spp) with increasing age. In fact, microscopic observations showed higher proportions of tissues from Cyperaceae, especially at profile depths where the contents of these sugars are the highest, namely at $25-27.5 \mathrm{~cm}$ and 40-42.5 $\mathrm{cm}$ in the DRY situation and at 30-32.5 and $47.5 \mathrm{~cm}$ at the WET site (results not shown). These findings agree with and support the previous observations by Comont et al. (2006) reported above. Other possibilities that we discarded are that the changes in the considered ratio values with depth could rather reflect a preferential degradation of Sphagnum spp. and/or changes in environmental conditions. However, Sphagnum mosses are wellknown for their refractory character, this point being further discussed later, and moreover, peatland evolution involves a number of dynamic stages characterised by a specific water regime and specific plant communities. A fen is thus characterised by water supplied from the underlying water table and by the predominance of Cyperaceae spp. (Manneville et al. 1999; Payette \& Rochefort 2001). Changes to a fen may occur up to the optimal stage of a bog. In 
the current state of understanding, the "Forbonnet" peatland is situated between a transitional fen and a raised bog with primarily an ombrotrophic supply with vegetation dominated by Sphagnum spp. communities. Changes in the $(\mathrm{Xy}+\mathrm{Ar}) /(\mathrm{Ga}+\mathrm{Rh}+\mathrm{Ma})$ ratio with depth could thus reflect and document this typical change in environmental conditions. However, given the analytical errors (15\%), the difference in the considered ratio value at both sites (DRY and WET) might not be really significant. It cannot therefore be assumed that there was a greater abundance of Cyperaceae in the DRY situation even if arabinose contents are significantly higher in the DRY than in the WET site (Figure 5). In turn, if the differences between both sites are not really discriminatory in terms of original plant input, they can be attributed with even greater confidence to OM decay and consequently to the impact of different environmental conditions between DRY and WET situations.

\section{OM decay in WET and DRY sites}

Micro-morphological observations show increasing transformation of plant tissues with depth (Figure 4). As already observed elsewhere (Bourdon et al., 2000) the decrease in the proportions of non-degraded plant tissues is counterbalanced by an increase in those of mucilage which is considered to be partly derived from in situ microbial syntheses (LaggounDéfarge et al. 1999). Although this depth-related trend is observed in both environmental conditions, OM degradation is lower in the WET than in the DRY site. This is evidenced by the overall higher proportions of well-preserved tissues and the lower percentages of mucilage in the WET site, and also by the presence of more abundant fungal hyphae in the DRY site, especially at 21, 36 and 44cm depth (Figure 4d). OM degradation is obviously faster in the upper $25 \mathrm{~cm}$ in the DRY site while it is much more progressive in the WET condition. However, except in the superficial levels where there is slightly more amorphous OM in the DRY than in the WET condition, this type of particulate material (much more probably inherited from plant tissues than from other -e.g. microbial- sources; Laggoun-Défarge et al. 1999), does not enable a distinction between the two sites in the investigated depth interval. Bourdon et al. (2000) reported the total loss of structure of ligno-cellulosic tissues of Cyperaceae with the concomitant formation of amorphous OM, preferentially in the superficial peat levels in a rather comparable way to what we observe here in the DRY situation. This and other results show that the destructuring of plant tissues depends on water table fluctuations: in DRY conditions, it occurs primarily in superficial peat while in WET conditions it affects tissues throughout the profiles analysed (Figure 4a). Furthermore and in 
contrast to the conclusions of Bourdon et al. (2000), our results show that the destructuring of plant tissues is not accompanied by an increase in AOM regardless of the environmental condition (Figure 4c). The amorphisation of inherited plant tissues is thus not a major discriminatory process of the early diagenesis affecting OM, even in the DRY condition in which degradation is greater especially when considering the relatively low proportions of well-preserved plant tissues all along the analysed peat section.

TOC increases with depth particularly in the WET site (Figure 3a). In the absence of significant mineral matter contribution the downward TOC rise can only be explained by the progressive loss of other organic elements. As the HI remains relatively constant along the profiles, the major contributor to the TOC increase certainly arises from the loss of oxygen as expressed by decreasing OI values with increasing depth. OM decay would thus preferentially affect the most oxygenated compounds that would thus form the most diagenetic sensitive OM pool. The differences in TOC observed in the upper $25 \mathrm{~cm}$ between WET and DRY sites could thus be explained by a preferential loss of oxygen compounds in the DRY condition, presumably because of more pronounced fluctuations of the water table at this location. The greater loss of diagenetic sensitive OM in the DRY situation is also shown by the lower R400 and R330 ratios in DRY compared to WET conditions (Figure 3d-e) particularly in the upper peat section $(0-25 \mathrm{~cm})$. Heat-vaporisable substances (R330) and the most thermolabile biopolymers (R400) are thus specifically affected during the earliest stages of diagenesis. There are few differences between both these parameters, most variations in the R400 signal being explained by changes in the proportions of compounds released below $330^{\circ} \mathrm{C}$ (and thus taken into account in the R330 parameter). Cellulose - which decomposes at around $350^{\circ} \mathrm{C}$ (Disnar \& Trichet 1984; Disnar et al. 2003; Sebag et al. 2006) - is relatively unaffected by the early diagenesis processes in the WET condition in contrast to the DRY site where it undergoes more intense degradation. Nevertheless and in the present state of knowledge, it can be assumed that the most diagenetically sensitive $\mathrm{OM}$ fraction, released below $330^{\circ} \mathrm{C}$, is made of biological macromolecules with low thermal and biological resistance, typical of fresh plant material (Disnar et al. 2003; Sebag et al., 2006). Consequently, a such organic component could be considered as a labile $\mathrm{C}$ pool. The progress of humification as expressed by the pyrophosphate index (PPI; Figure 3b) is the opposite of the behaviour of labile OM seen by R330. In addition to a clear distinction between both sites, the increase in the PPI with increasing depth shows greater humification at the DRY site.

\section{Carbohydrate dynamics in WET and DRY sites}


Recent peat OM is composed of more or less altered inherited biochemical compounds such as hemicellulose and cellulose, and additionally of products of in situ microbial syntheses, i.e. mainly exopolysaccharides. Depending on OM sources and degradation, the carbohydrate monomers exhibit distinctive composition patterns. In this work, we therefore used the abundance of individual monosaccharides to identify specific signatures of phyto-inheritance and to trace original plant contributions to the peat. In addition, relative changes in their proportions were investigated in order to assess in situ production by microbial syntheses.

In full agreement with previous conclusions of Comont et al (2006), high total sugar contents (between 210 and $395 \mathrm{mg}^{-1} \mathrm{~g}^{-1}$ ) show their overall preservation regardless of wetness situation. The slight decrease in total sugars with depth at the WET site reveals a constantly and slightly increasing degradation (Figure 5) consistently with results obtained with other bioindicators (see above). In the DRY conditions, this degradation is more chaotic: the substantial variations in cellulose sugars that are the structural sugars of plant tissues, explain most changes in total sugars that appear to be a prime target of botanical precursor degradation (Table 1). Accordingly, the latter degradation would seem to occur primarily by the loss of cellulose tissue structure. Again, this finding agrees with the results of Comont et al. (2006), although in our case, destructured cellulose does not apparently contribute to any enrichment in the hemicellulose carbohydrate pool, primarily hemicellulose glucose (Figure 5).

Our results show the increase in the $(\mathrm{Xy}+\mathrm{Ar}) /(\mathrm{Ga}+\mathrm{Rh}+\mathrm{Ma})$ ratio with depth, either because of changes in environmental conditions or by a preferential degradation of Sphagnum spp. The latter hypothesis is improbable since peat moss is considered to be inherently degradationresistant (Van Breemen 1995). In fact, aside from this intrinsic resistance, Sphagnum spp. induces local conditions unfavourable for the development of micro-organisms (Painter 1991). In addition, many authors (Coulson \& Butterfield 1978; Clymo \& Hayward 1982; Chague-Goff \& Fyfe 1996, Laggoun-Défarge et al 2008) have also shown that Sphagnum spp. is less degradable than Cyperaceae. Thus, as discussed above, increasing $(\mathrm{Xy}+\mathrm{Ar}) /(\mathrm{Ga}+\mathrm{Rh}+\mathrm{Ma})$ ratio with depth could reflect typical changes in communities (from sedges in the bottom of the profile to Sphagnum spp in the top of the peat layer) induced by changes in environmental conditions.

In addition to the monomers used as markers of botanical sources, four other sugars, namely ribose, fucose, allose and lyxose, were present, albeit in smaller proportions (Table 1). Ribose has previously been assumed to be a microbial marker in peat bogs (Comont et al. 2006). As a matter of fact ribose is a constituent of RNA and additionally of some molecules involved in 
metabolic activity. Comont et al. (2006) also assigned fucose to an enzymatic degradation product, but few studies have so far ascribed the presence of this sugar to microbial input. Jia et al. (2008) on the contrary showed that fucose is a constituent of peat moss, present at concentrations between 1.8 and 5.6 mg.g ${ }^{-1}$ depending on the Sphagnum precursor considered. In our work fucose varied within the same range of concentration (1.0 to $6.0 \mathrm{mg}^{-1} \mathrm{~g}^{-1}$; Table 1 ), but independently of ribose variation. Therefore, its precise source remains unelucidated in the peat profiles studied. Ribose concentrations in the first $25 \mathrm{~cm}$ peat section analysed show that microbial activity is indeed higher in DRY conditions (Table 1) as assumed after the evidence of a greater degradation at this site (e.g. higher percentages of mycelial hyphae; Figure 4d). Allose and lyxose which are rarely investigated in peatlands were present in low and variable quantities in our samples (Figure 5; Table 1). Allose, whose origin remains unknown, was present in relatively high contents (ca. $5 \mathrm{mg} \cdot \mathrm{g}^{-1}$ ) in only two peat levels of the WET site. According to Khoo et al. (1996) lyxose can be found in mycobacteria (actinomycetes). The analysis of phospholipid fatty acids (PLFAs) carried out on the same peat showed that PLFAs $18: 2 \omega 6$, common in many species of fungi, were detected only between 5 and $15 \mathrm{~cm}$ depth (Grasset, unpublished data) where lyxose concentrations were higher and microscopic observations revealed high proportions of fungal hyphae. Taken together, these results suggest that lyxose can be used as a marker of fungal activity.

\section{CONCLUSION}

Combined carbohydrate indicators and bulk organic matter (OM) analyses (Rock Eval pyrolysis, microscopy and pyrophosphate index) conducted on peat profiles of $50 \mathrm{~cm}$ depth from Le Forbonnet Sphagnum peatland allowed us to obtain information on changes in OM sources and their early diagenetic transformation in relation to different hydrological conditions. The main results are as summarised below:

- Most bioindicators showed that OM decay increased with depth in both DRY and WET sites.

- In comparison to DRY condition, OM degradation was lower in the WET site as evidenced by higher proportions of well-preserved tissues, and lower mucilage percentages and pyrophosphate index values. The progress of OM decay with depth was gradual in the WET condition while it appeared to be faster in the upper $25 \mathrm{~cm}$ peat layer of the DRY site probably as a consequence of more pronounced water table fluctuations in the latter site. 
- Rock Eval pyrolysis results showed that the most diagenetically sensitive OM fraction, released below $330^{\circ} \mathrm{C}$, was made of biological macromolecules with low thermal and biological resistance, typical of fresh plant material OM. In addition, this OM fraction which was made of the most oxygenated compounds would preferentially be affected by decay processes. In the DRY site, decay was shown by a loss of this OM fraction which effectively appeared to be the most labile OM.

- Carbohydrate dynamics in both DRY and WET sites allowed us to identify ribose and lyxose as markers of bacterial and/or fungal activities in peat bogs.

Overall, our results suggest that water level changes preferentially impact biochemical changes of labile oxygenated-OM, believed to be the most sensitive to hydrological variations, particularly to drought events whose frequency may increase in the oncoming climate changes. It is therefore essential to biochemically characterise labile OM in order to provide suitable tools for accurate estimations of $C$ losses in peatlands.

\section{ACKNOWLEDGEMENTS}

This article is a contribution of the PEATWARM project (Effect of moderate warming on the functioning of Sphagnum peatlands and their function as carbon sink). PEATWARM is supported by the French National Agency for Research under the "Vulnerability: Environment - Climate" Program (ANR-07-VUL-010). The authors acknowledge the Regional Scientific Council of Natural Heritage of the Franche Comté Region that gave permission to perform the experiments in the Regional Natural Reserve of Forbonnet. They gratefully acknowledge R. Boscardin and M. Hatton for analytical assistance and C. Défarge for advice regarding spectrophometer analyses. They gratefully acknowledge C. Défarge for advices regarding spectrophometer analyses and R. Boscardin and M. Hatton for analytical assistance. E. Rowley-Jolivet has revised the English version. Authors also are grateful to the two anonymous reviewers for their constructive comments and helpful suggestions on earlier version of the manuscript.

\section{REFERENCES}

Bailly G (2005) Suivi floristique de la tourbière vivante de Frasne. Internal report

Belyea LR (1996) Separating the effects of litter quality and microenvironment on 
decomposition rates in a patterned peatland. Oikos 77(3): 529-539

Belyea LR, Malmer N (2004) Carbon sequestration in peatland: patterns and mechanisms of response to climate change. Global Change Biology 10: 1043-1052

Bethge PO, Holmström C, Juhlin S (1996) Quantitative gas chromatography of mixtures of simple sugars. Svensk Papperstidning arg 69: 60-63

Bortoluzzi E, Epron D, Siegenthaler A et al (2006) Carbon balance of a European mountain bog at contrasting stages of regeneration. New Phytologist 172(4): 708-718

Bourdon S, Laggoun-Défarge F, Disnar JR et al (2000) Organic matter sources and early diagenetic degradation in a tropical peaty marsh (Tritrivakely, Madagascar). Implications for environmental reconstruction during the Sub-Atlantic. Organic Geochemistry 31: 421-438

Bridgham SD, Ping CL, Richardson JL et al (2001) Soils of northern peatlands: histosols and gelisols. In: Richardson J. L., Vepraskas M. J. (eds) Wetland soils: their genesis, hydrology, landscape and separation into hydric and nonhydric soils. Ann Arbor Press, pp. 343-370.

Bubier JL, Frolking S, Crill PM et al (1999) Net ecosystem productivity and its uncertainty in a diverse boreal peatland. Journal of Geophysical Research-Atmospheres 104(D22): 683-692

Chague-Goff C, Fyfe WS (1996) Geochemical and petrographical characteristics of a domed bog, Nova Scotia: a modern analogue for temperate coal deposits. Organic Geochemistry 24: $141-158$

Christensen TR, Friborg T, Sommerkorn M et al (2000) Trace gas exchange in a high-arctic valley 1. Variations in $\mathrm{CO}_{2}$ and $\mathrm{CH}_{4}$ flux between tundra vegetation types. Global Biogeochemical Cycles 14(3): 701-713

Clymo RS (1983) Peat. In: Gore AJP (ed). Ecosystems of the world, 4A. Mires: swamp, bog, fen and moor, General Studies. Elsevier, Amsterdam, p 159

Clymo RS, Hayward PM (1982) The ecology of Sphagnum. In Smith AJE (ed) Bryophyte 
Ecology. Chapman \& Hall, London, New York, pp229-289

Comont L, Laggoun-Défarge F, Disnar JR (2006) Evolution of organic matter indicators in response to major environmental changes: the case of a formerly cut-over peatbog (Le Russey, Jura Mountains, France). Organic Geochemistry 37: 1736-1751

Coulson JC, Butterfield J (1978) An investigation of the biotic factors determining the rates of plant decomposition on blanket bog. Journal of Ecology 66: 631-650

Di-Giovanni Ch, Disnar JR, Bichet V et al. (1998) Geochemical characterization of soil organic matter and variability of a post detrital organic supply (Chaillexon lake, France). Earth Surface Processes and Landforms 23 : 1057-1069

Disnar JR, Guillet B, Keravis D et al (2003) Soil organic matter (SOM) characterization by Rock-Eval pyrolysis: scope and limitations. Organic Geochemistry 34(3): 327-343

Disnar JR, Jacob J, Morched-Issa M et al (2008) Assessment of peat quality by molecular and bulk geochemical analysis: Application to the Holocene record of the Chautagne marsh (Haute Savoir, France). Chemical Geology 254:101-112

Disnar JR, Trichet $\mathrm{J}$ (1984) The influence of various divalent cations $\left(\mathrm{UO}_{2}{ }^{2+}, \mathrm{Cu}^{2+}, \mathrm{Pb}^{2+}\right.$, $\mathrm{Co}^{2+}, \mathrm{Ni}^{2+}, \mathrm{Zn}^{2+}, \mathrm{Mn}^{2+}$ ) on thermally induced evolution of organic matter isolated from an algal mat. Organic Geochemistry 6: 865-874

Dorrepaal E, Toet S, van Logtestijn RSP, et al (2009) Carbon respiration from subsurface peat accelerated by climate warming in the subarctic. Nature 460: 616-619

Espitalié J, Deroo G, Marquis F (1985a) La pyrolyse Rock-Eval et ses applications, première partie. Revue de l’Institut Français du Pétrole 40: 563-579

Espitalié J, Deroo G, Marquis F (1985b) La pyrolyse Rock-Eval et ses applications, deuxième partie. Revue de l’Institut Français du Pétrole 40: 755-784

Francez AJ (2000) La dynamique du carbone dans les tourbières à Sphagnum, de la sphaigne 
à l'effet de serre. Année Biologique 39: 205-270

Gerdol R (1995) The growth dynamics of Sphagnum based on field-measurements in a temperate bog and on laboratory cultures. Journal of Ecology 83(3): 431-437

Gobat JM, Aragno M, Matthey Y (1986) The living soil: fundamentals of soil science and soil biology. Science publishers, Enfield

Gore AJP (1983) Ecosystems of the world, 4A. Mires: swamp, bog, fen and moor, General Studies. Elsevier, Amsterdam

Gorham E (1991) Northern peatlands - role in the carbon-cycle and probable responses to climatic warming. Ecological Applications 1(2): 182-195

Gunnarsson U (2005) Global patterns of Sphagnum productivity. Journal of Bryology 27: 269-279

Hamilton SE, Hedges JI (1988) The comparative geochemistries of lignins and carbohydrates in an anoxic fjord. Geochimica et Cosmochimica Acta 52(1): 129-142

Heikkinen JEP, Elsakov V, Martikainen PJ (2002) Carbon dioxide and methane dynamics and annual carbon balance in tundra wetland in NE Europe, Russia. Global Biogeochemical Cycles 16(4): 1115. DOI 10.1029/2002GB001930

Hogg EH, Malmer N, Wallen B (1994) Microsite and regional variation in the potential decay rate of Sphagnum-magellanicum in south swedish raised bogs. Ecography 17(1): 50-59

Houghton JT, Ding Y, Griggs DJ et al (2001) Climate Change 2001: the Scientific Basis. Third IPCC Report, Cambridge University Press, Cambridge

Jia GD, Dungait JAJ, Bingham EM et al (2008) Neutral monosaccharides as biomarker proxies for bog-forming plants for application to palaeovegetation reconstruction in ombrotrophic peat deposits. Organic Geochemistry 39(12): 1790-1799 
Johnson LC, Damman AWH (1991) Species-controlled Sphagnum decay on a south swedish raised bog. Oikos 61(2): 234-242

Kaila A (1956) Determination of the degree of humification of peat samples. Journal of Scientific Agricultural Society of Finland 28:18-35

Khoo KH, Suzuki R, Dell A et al (1996) Chemistry of the lyxose-containing mycobacteriophage receptors of Mycobacterium phlei Mycobacterium smegmatis. Biochemistry 35(36): 11812-11819

Kirschbaüm MUF (1995) The temperature dependence of soil organic-matter decomposition and the effect of global warming on soil organic-C storage. Soil Biology \& Biochemistry 27(6): 753-760

Lafargue E, Marquis F, Pillot D (1998) Rock- Eval 6 applications in hydrocarbon exploration, production and soil contamination studies. Revue de l'Institut Français du Pétrole 53: 421-437

Laggoun-Défarge F, Mitchell EAD, Gilbert D et al (2008) Cutover peatland regeneration assessment using organic matter and microbial indicators (bacteria and testate amoebae). Journal of Applied Ecology 45: 716-727

Laggoun-Défarge F, Bourdon S, Chenu C et al (1999) Etude des transformations morphologiques précoces des tissus végétaux de tourbe. Apport du marquage histochimique en MET et du cryo-MEB haute résolution. In: Elsass F, Jaunet AM (eds) Structure et Ultrastructure des Sols et des Organismes Vivants. INRA, Paris, p169

Maltby E, Immirzi CP (1993) Carbon dynamics in peatlands and other wetland soils-regional and global perspectives. Chemosphere 27: 999-1023

Manneville O, Vergne V, Villepoux O et al (1999) - Le monde des tourbières et des marais Belgique, France, Luxembourg, Suisse. Delachaux-Niestlé, Paris, Lausanne

Moers MEC, Baas M, Deleeuw JW et al (1990) Occurrence and origin of carbohydrates in peat samples from a red mangrove environment as reflected by abundances of neutral 
monosaccharides. Geochimica et Cosmochimica Acta 54(9): 2463-2472

Moers MEC, Boon JJ, Deleeuw JW et al (1989) Carbohydrates speciation and PY-MS mapping of peat samples from a sub-tropical open marsh environment. Geochimica et Cosmochimica Acta 53(8): 2011-2021

Moore TR, Knowles R (1990) Methane emissions from fen, bog and swamp peatlands in Quebec. Biogeochemistry 11: 45-61

Noël H (2001) Caractérisation et calibration des flux organiques sédimentaires dérivant du bassin versant et de la production aquatique (Annecy, Le Petit Lac). Rôles respectifs de l’Homme et du Climat sur l'évolution des flux organiques au cours des 6000 dernières années. Dissertation, University of Orleans

Økland RH, Øland T, Rydgren K (2001) A Scandinavian perspective on ecological gradients in north-west European mires: reply to Wheeler and Proctor. Journal of Ecology 89: 481-486

Painter TJ (1991) Lindow man, tollund man and other peat-bog bodies: The preservative and antimicrobial action of Sphagnan, a reactive glycuronoglycan with tanning and sequestering properties, Carbohydrate Polymers, Vol. 15, p. 123-142

Payette S, Rochefort L (2001) Ecologie des tourbières du Québec-Labrador. Les Presses de l’Université de Laval, Saint-Nicolas

Pedersen A (1975) Growth measurements of five Sphagnum species in south Norway. Norwegian Journal of Botany 22: 277-284

Popper ZA, Fry SC (2003) Primary cell wall composition of bryophytes and charophytes. Annals of Botany 91(1): 1-12

Schnitzer M (1967) Humic fulvic acid relationships in the organic soils and humification of organic matter in these soils. Can. J. Soil Sci. 47: 245-250

Sebag D, Disnar JR, Guillet B et al (2006) Monitoring organic matter dynamics in soil 
profiles by 'Rock-Eval pyrolysis': bulk characterization and quantification of degradation. European Journal of Soil Science 57(3): 344-355

Strack M, Waddington JM, Rochefort L et al (2006) Response of vegetation and net ecosystem carbon dioxide exchange at different peatland microforms following water table drawdown. Journal of Geophysical Research-Biogeosciences 111: G02006. DOI 10.1029/2005JG000145

Van Breemen N (1995) How Sphagnum bogs down other plants. Trends in Ecology and Evolution 10: 270-275

Waddington JM, Roulet NT (1996) Atmosphere-wetland carbon exchanges: Scale dependency of $\mathrm{CO}_{2}$ and $\mathrm{CH}_{4}$ exchange on the developmental topography of a peatland. Global Biogeochemical Cycles 10(2): 233-245

Wheeler BD, Proctor MCF, (2000) Ecological gradients, subdivisions and terminology of north-west European mires. Journal of Ecology 88: 187-203

Wicks RJ, Moran MA, Pittman LJ et al (1991) Carbohydrate signatures of aquatic macrophytes and their dissolved degradation products as determined by a sensitive highperformance ion chromatography method. Applied and Environmental Microbiology 57(11): 3135-3143 


\section{FIGURE CAPTIONS}

Figure 1. Location of the studied area within Le Forbonnet ombrotrophic bog (Jura Mountains, France).

Figure 2. R330 and R400 parameters of Rock Eval pyrolysis. The whole pick (S2, expressed in mg of hydrocarbons per g of sample) corresponds to the quantity of hydrocarbons released during pyrolysis, The R400 ratio represents the part of the S2 signal produced below $400^{\circ} \mathrm{C}$ compared to the total S2 signal. The R330 ratio is the part of the S2 signal produced below $330^{\circ} \mathrm{C}$ compared to the total S2 signal.

Figure 3. Depth evolution of (a) Total Organic Carbon (TOC, \%), (b) PyroPhosphate Index (PPI, arbitrary units), (c) Hydrogen Index (HI, mg HC.g ${ }^{-1}$ TOC), (d) Oxygen Index (OI, mg $\mathrm{O}_{2} \cdot \mathrm{g}^{-1}$ TOC) and the two ratios calculated from Rock-Eval pyrolysis parameters (e) R400 and (f) R330 (see figure 2).

Standard deviation $\mathrm{n}=3$ (WET: cores 7, 11 and 12; DRY: cores 1, 2 and 4). Without standard deviation $\mathrm{n}=1$ (DRY: core 1; WET: core 12).

Figure 4. Depth evolution of relative percentages of organic micro-remains of bulk peat using transmitted light microscopy: (a) Well-preserved tissues, (b) Mucilage, (c) Amorphous organic matter, (d) Fungal hyphae.

Standard deviation $\mathrm{n}=3$ (WET: core 7, 11 and 12; DRY: core 1, 2 and 4). Without standard deviation $\mathrm{n}=1$ (DRY: core 1; WET: core 12).

Figure 5. Depth profiles of the amounts of total neutral, cellulose and hemicellulose sugars, and distribution of hemicellulose sugars (Hemicellulosic-glucose, xylose, arabinose, galactose, rhamnose, mannose, fucose, allose, ribose and lyxose) and the $(\mathrm{Xy}+\mathrm{Ar}) /(\mathrm{Ga}+\mathrm{Rh}+\mathrm{Ma})$ ratio. All yields are expressed in mg. $\mathrm{g}^{-1}$ of dry peat. 
n = 1 (DRY: core 1 ; WET: core 12)
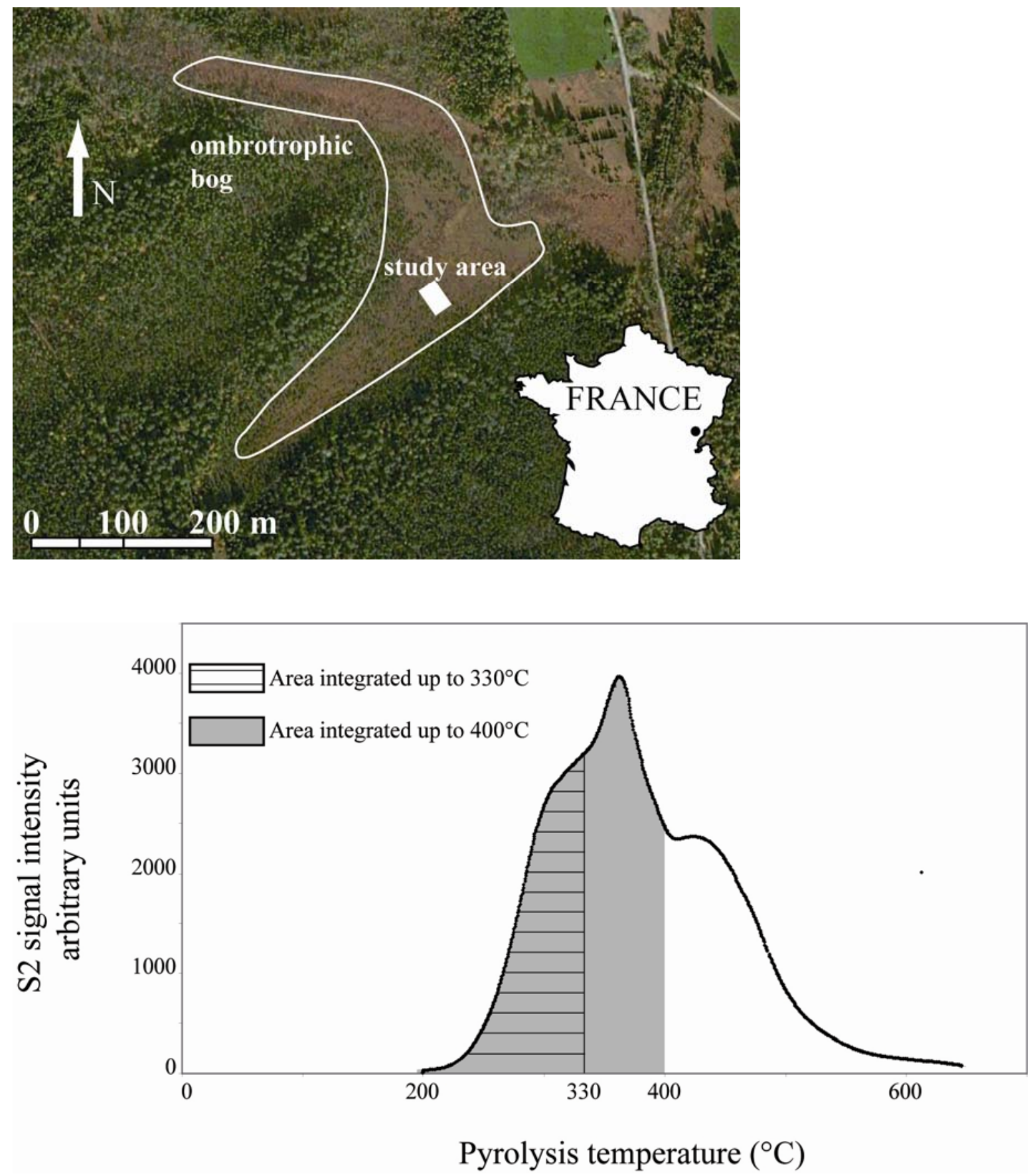

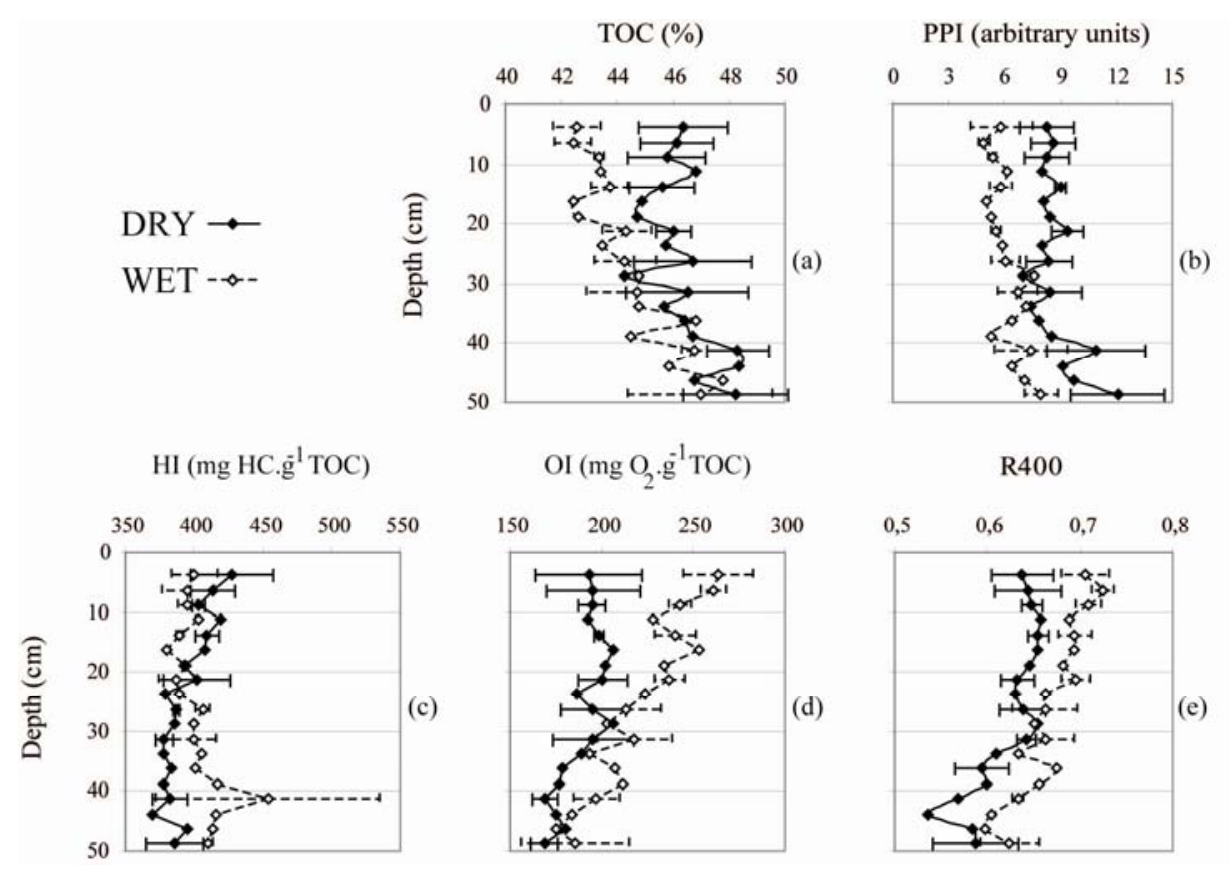

$$
\left.\mathrm{OI} \text { (mg } \mathrm{m}_{2} \cdot \mathrm{g}^{-1} \mathrm{TOC}\right)
$$

R400
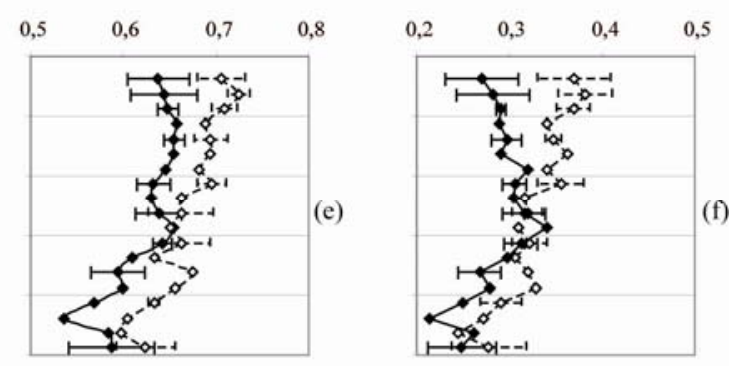

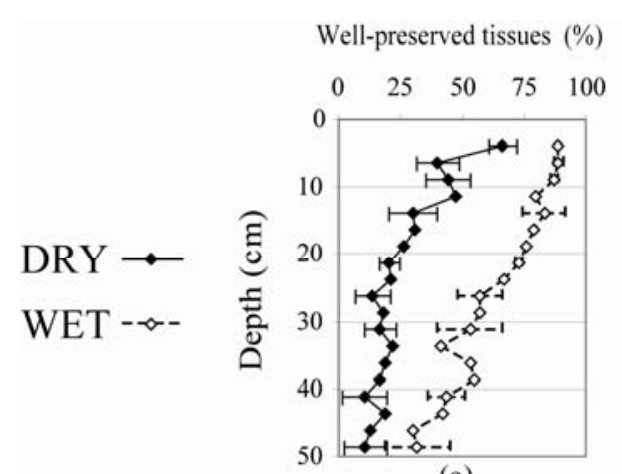

(a)

$$
\text { Mucilage (\%) }
$$

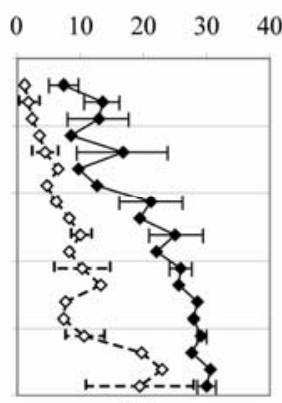

(b)
Amorphous organic matter (\%)

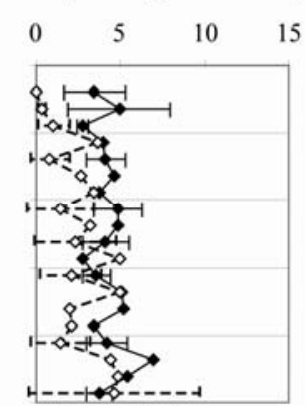

(c)
Fungal hyphae (\%)

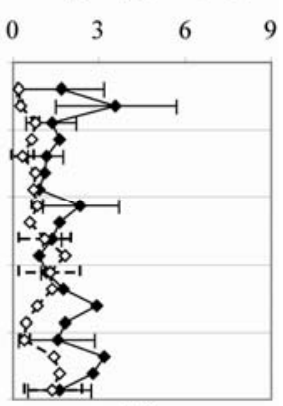

(d) 

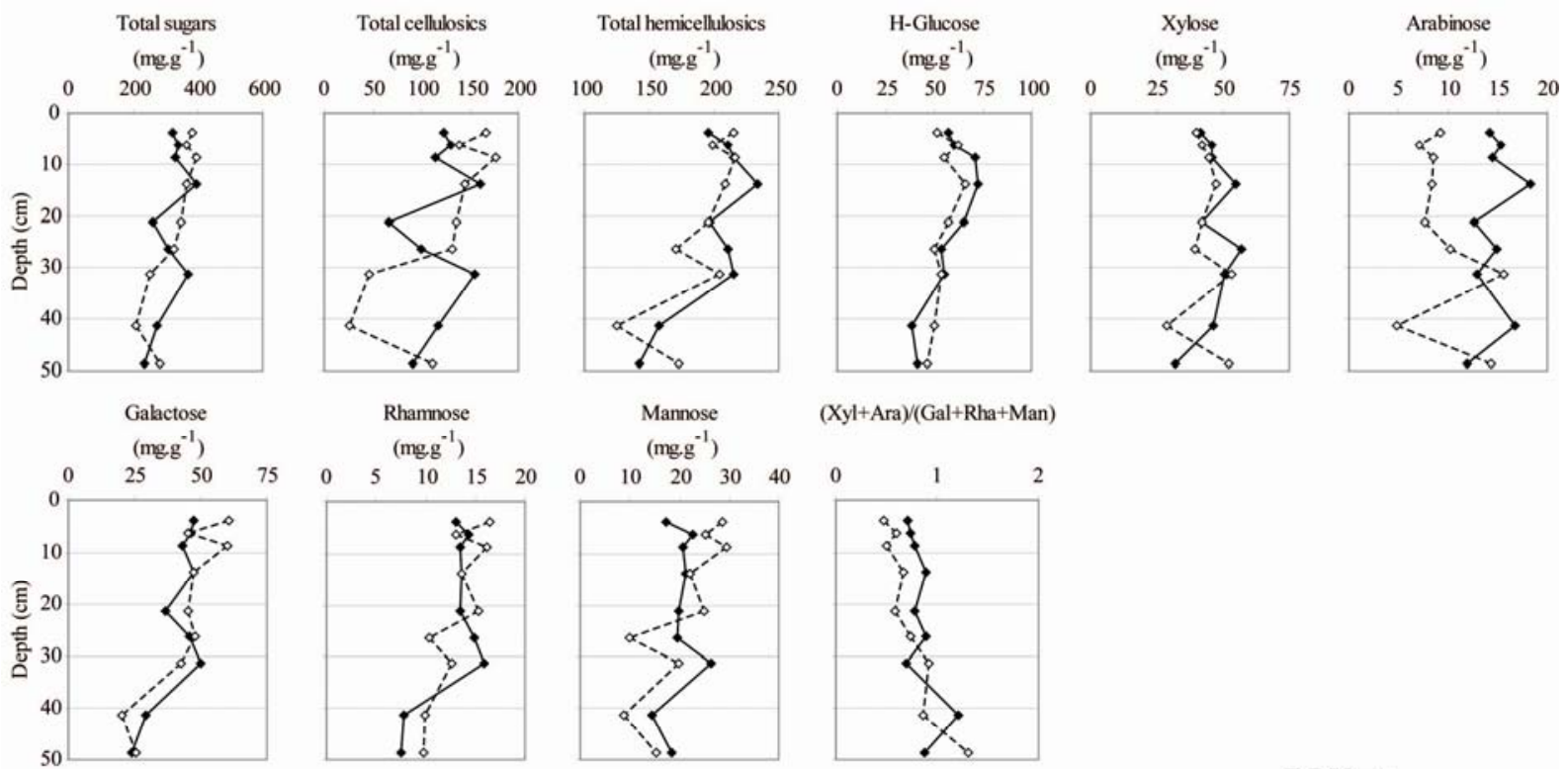

(Xyl+Ara)/(Gal+Rha+Man)
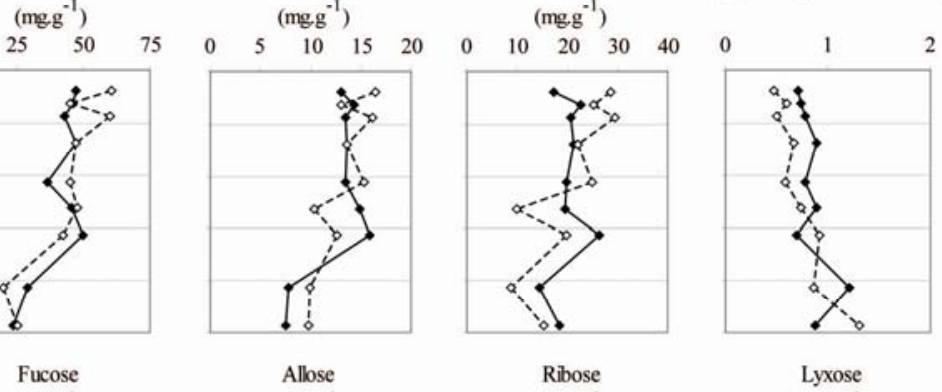

Ribose

(mg. ${ }^{-1}$ )

(mg $\mathrm{g}^{-1}$ )
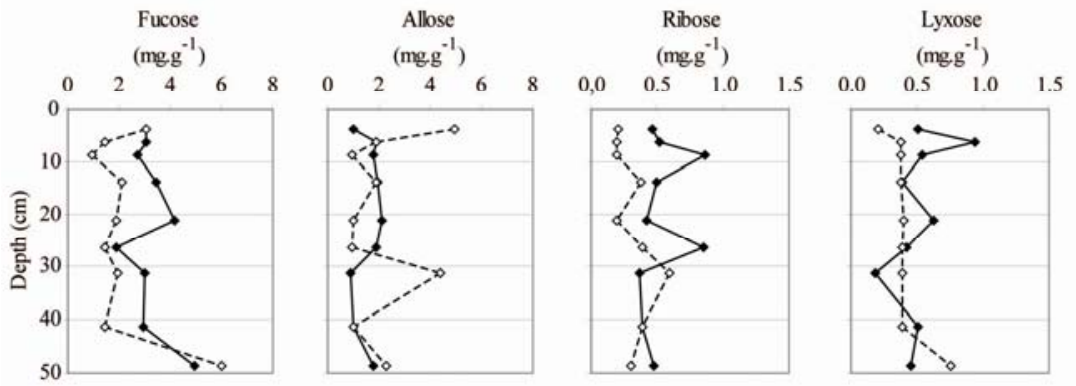

DRY $\rightarrow$

WET $\rightarrow-$ 


\section{TABLES}

Table 1. Depth changes of neutral sugar yields (mg.g ${ }^{-1}$ of sample) of bulk peat from WET and DRY conditions of Le Forbonnet peatland (DRY: core 1; WET: core 12)

\begin{tabular}{|c|c|c|c|c|c|c|c|c|c|c|c|c|c|c|}
\hline $\begin{array}{l}\stackrel{0}{0} \\
\stackrel{\mathbb{Z}}{*}\end{array}$ & 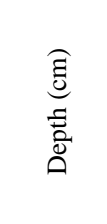 & 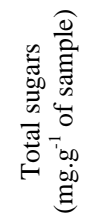 & 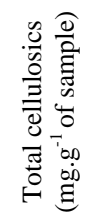 & 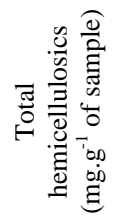 & 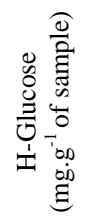 & 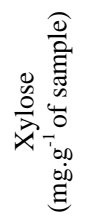 & 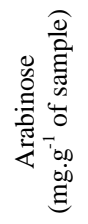 & 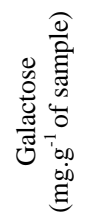 & 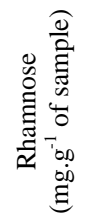 & 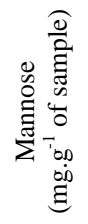 & 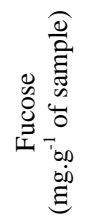 & 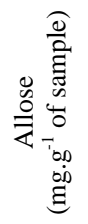 & 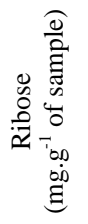 & 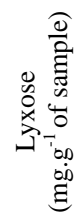 \\
\hline \multirow[t]{8}{*}{ WET } & $2,5-5$ & 381,8 & 167,0 & 214,8 & 51,5 & 40,0 & 9,2 & 60,5 & 16,4 & 28,7 & 3,1 & 5,0 & 0,2 & 0,2 \\
\hline & $7,5-10$ & 395,6 & 177,4 & 216,5 & 55,0 & 44,8 & 8,6 & 60,0 & 16,2 & 29,5 & 1,0 & 0,9 & 0,2 & 0,4 \\
\hline & $12,5-15$ & 365,5 & 144,4 & 209,0 & 66,0 & 47,1 & 8,4 & 47,1 & 13,6 & 22,0 & 2,1 & 1,9 & 0,4 & 0,4 \\
\hline & $20-22,5$ & 346,5 & 136,8 & 195,9 & 57,4 & 42,1 & 7,7 & 45,0 & 15,3 & 24,9 & 1,9 & 1,0 & 0,2 & 0,4 \\
\hline & $25-27,5$ & 328,2 & 131,6 & 170,7 & 50,0 & 39,3 & 10,3 & 47,7 & 10,4 & 9,9 & 1,4 & 1,0 & 0,4 & 0,4 \\
\hline & $30-32,5$ & 250,5 & 45,7 & 204,8 & 53,4 & 53,4 & 15,5 & 42,7 & 12,6 & 19,8 & 1,9 & 4,4 & 0,6 & 0,4 \\
\hline & $40-42,5$ & 209,9 & 26,7 & 125,2 & 49,8 & 28,6 & 4,9 & 20,0 & 9,9 & 8,8 & 1,5 & 1,0 & 0,4 & 0,4 \\
\hline & $47,5-50$ & 284,7 & 112,0 & 172,7 & 46,6 & 51,9 & 14,3 & 25,6 & 9,8 & 15,2 & 6,0 & 2,3 & 0,3 & 0,8 \\
\hline \multirow[t]{8}{*}{ DRY } & $2,5-5$ & 319,7 & 123,7 & 196,0 & 57,6 & 41,4 & 14,1 & 47,5 & 13,1 & 17,3 & 3,0 & 1,0 & 0,5 & 0,5 \\
\hline & $5-7,5$ & 340,9 & 129,9 & 211,0 & 60,4 & 45,6 & 15,4 & 46,2 & 14,4 & 22,6 & 3,1 & 1,9 & 0,5 & 0,9 \\
\hline & $7,5-10$ & 329,1 & 114,1 & 215,0 & 71,2 & 45,9 & 14,4 & 43,2 & 13,5 & 20,8 & 2,7 & 1,8 & 0,9 & 0,5 \\
\hline & $12,5-15$ & 395,4 & 161,5 & 233,9 & 72,2 & 54,6 & 18,3 & 47,5 & 13,7 & 21,3 & 3,5 & 2,0 & 0,5 & 0,4 \\
\hline & $20-22,5$ & 262,8 & 66,1 & 196,7 & 64,9 & 41,9 & 12,6 & 36,6 & 13,5 & 19,9 & 4,2 & 2,1 & 0,4 & 0,6 \\
\hline & $25-27,5$ & 310,7 & 100,1 & 210,6 & 53,3 & 57,0 & 15,0 & 45,8 & 15,0 & 19,6 & 1,9 & 1,9 & 0,8 & 0,4 \\
\hline & $30-32,5$ & 370,1 & 154,7 & 215,4 & 55,2 & 50,7 & 12,9 & 49,8 & 15,9 & 26,4 & 3,0 & 0,9 & 0,4 & 0,2 \\
\hline & $40-42,5$ & 275,7 & 118,0 & 157,6 & 38,2 & 46,1 & 16,7 & 29,4 & 7,8 & 14,6 & 2,9 & 1,0 & 0,4 & 0,5 \\
\hline
\end{tabular}


